DOI https://doi.org/10.18551/rjoas.2017-010.22

\title{
THE IMPACT OF JOB PERFORMANCE AND REWARD SYSTEM AS A MEDIATOR AND MODERATOR VARIABLE BETWEEN ORGANIZATIONAL COMMITMENT AND JOB SATISFACTION OF LECTURERS AT PRIVATE COLLEGES IN EAST JAVA, INDONESIA
}

\author{
Fathorrahman \\ Management Program, STIE ASIA, Malang, Indonesia \\ E-mail: faturrahman.asia.74@gmail.com
}

\begin{abstract}
The quality of a college is determined by many components, one of which is lecturers. Lecturers at colleges play a strategic role in improving college's quality. There are opinions stating that the quality of an education can be improved by first improving the lecturers' quality. Lecturers' job satisfaction and job performance become important topics to review in order to improve the lecturers' quality. This is a causality research which uses stratified random sampling method with 105 lecturers as the sample, and 95 respondents who submit the questionnaires in a complete manner. The results of hypotheses testing from this research are as follows: (1) Organizational commitment has a positive impact on lecturers' job performance; (2) Job performance has a positive impact on lecturers' job satisfaction; (3) Organizational commitment has a positive impact on lecturers' job satisfaction; (4) Job performance mediates the correlation between organizational commitment and lecturers' job satisfactionl; and (5) Reward system moderates the correlation between lecturers' job performance and job satisfaction.
\end{abstract}

\section{KEY WORDS}

Organizational commitment, job satisfaction, job performance, reward system.

Globalization connects people in many aspects of life, such as politics, technology, socioculture, and economics (Giddens, 2001:5). The globalization progresses rapidly thanks to inventions in technology, communication and information. It even changes the world economic order and characteristics of business environment. It also begins to affect many life aspects, not excluding the field of education, and within it, the higher education. The society, as a result of the globalization, demands a better quality in higher education. This is only natural and has to be solved immediately. This means the learning process in colleges/higher education institutes should be highly qualified; it should meet the assigned standard of quality. A college's existency and challenges depend on its stakeholders' assessment of the college's quality.

The quality of a college is determined by many components, for example the quality of academic programs (college inputs, learning process, and college outputs/graduates), the human resource, the facilities and infrastructures, and the academic environment. Among the others, the human resource component, namely the lecturers, becomes significant in order to raise a college's quality.

Lecturers at colleges play a strategic role in academic and student development. There are opinions stating that the good quality of an education can be attained by first improving the lecturers' quality. Such opinion stems from the fact that lecturers become the agent of science and knowledge transformations towards the students; hence it is expected that the higher quality of a lecturer, the higher quality of students and graduates. What can be found in previous discovery is that "the man behind the system" plays significant role in education. Human resource is the key factor in determining the power of education. Moreover, education as a service industry is a "front line provider and determine the quality of service delivery system", which places lecturers in the front line in deciding the quality of service (Sallis, 2002:35). 


\section{THEORETICAL REVIEW AND HYPOTHESES}

Organizational commitment is the individual's attachment to the organization in which he/she works. There are three components of organizational commitment, namely affective commitment, continuance commitment, and normative commitment (Allen \& Meyer, 1990; Meyer \& Allen, 1997). Affective commitment deals with emotional attachment, identification, and involvement of employees within an organization. Continuance commitment deals with benefit considerations if some employees leave the organization. Lastly, normative commitment deals with the employees' sense of obligation to their organization.

It is related to the employees' job performance, that is, if employees are highly committed, they will be able to improve the organization's job performance. This is in accordance with the study conducted by DeCotiis and Summers (1987), which states that organizational commitment is a strong predictor against the employees' performance, and also Jaramillo et al., (2005) which states that between organizational commitment and performance there is a positive correlation towards sales and non sales employees. Still in parralel with the previous ideas, there are also studies by Chen and Francesco (2003), and Sudiro (2008). On the other hand, Yiing and Zaman (2009), shows an opposite result where commitment does not affect employees' job performance. Meanwhile Wiener and Vardi (1980) conclude that organizational commitment has an unclear relationship towards job performance. From the aforementioned study results, the writer develops the first hypothesis:

H1: Organizational commitment has a positive impact towards lecturers' job performance.

Study about the relationship of job satisfaction and performance becomes one of the most significant studies in industrial-organizational psychology. The interest towards the relationship between workplace behavior and productivity exists since the period of Hawthorne studies (Roethlisberger \& Dickson, 1939); and this topic continues to be researched until now, either quantitatively (Brayfield dan Crockett, 1955; Herzberg et al., 1957; Locke, 1970; Schwab \& Cummings, 1970) or quantitatively (Laffaldano \& Muchincky, 1985; Petty et al., 1984). However, Hawthorne studies are commonly preferential because they highlight the relationship between employees' behavior and job performance, and attract many researchers to investigate the relationshipAfter the Hawthrone studies, the most influential narrative review on the correlation between job satisfaction and performance is the one published by Brayfield and Crockett (1955). They conclude that between job satisfaction and job performance exists "minimal or no relationship".

Following Brayfield and Crockett (1955), several narrative reviews were published (Herzberg et al., 1957; Locke, 1970; Schwab \& Cummings, 1970; Vroom, 1964). But, these reviews are greatly different than the previous one: they express things concerning the correlation between job satisfaction and performance in an optimistic tone. Another research by Orpen (1986) observes employees in an electronic factory, and concludes that there is an insignificant correlation between job satisfaction and performance. Chen (2004) researched groups of employees in SME's (small and medium-sized enterprises) engaging in service as well as manufacture sectors, and found out there is no significant relationship between job satisfaction and employees' performance. A study on employees of wood manufacture also points out that the relationship between job satisfaction and performance is not significant (Michael et al., 2005; Gagnon and Michael, 2004). Other researches that results in a similar conclusion are those conducted by Joyce and Slocum (1984) dan Joyce et al. (1982).

It is evident from the previous researches that a controversy about the relationship between job satisfaction and job performance exists and becomes an interesting topic. Some opinions state that job satisfaction does have its impact on job performance, yet some others have the opposite opinion: it is the job performance that affects the job satisfaction (Judge et al., 2001). From the research results stated above, the writer develops the second hypothesis:

H2: Job performance has a positive impact on lecturers' job satisfaction.

The controversy between job satisfaction and job performance, according to Judge et al., enables developing a new research model by adding a moderator or mediator variable 
between work performance and satisfaction variables. Hence, in this research, the writer adds reward system as a variable that moderates the correlation between work performance and satisfaction variables. The writer tries to review and modify the research results of Porter and Lawler (1971) which was developed from Vroom's expectancy theory. The latter states that job satisfaction and performance are closely related although they can be resulted from different causes. Vroom assumes that reward system creates job satisfaction and in some cases job performance generates reward. Porter and Lawler in their research draws a conclusion that reward system, both extrinsically and intrinsically, moderates the correlation between job performance and satisfaction. This means when an employee feels that the reward he/she received does not match his/her job performance, then the job satisfaction will be weak.

In this research, modification of Porter and Lawler's concept is done by the writer's adding organizational commitment variable, which could also affect someone's job satisfaction. A commitment is understood as an employee's will to stay working for the organization (Meyer, 1997). Thus, an employee who has a strong organizational commitment towards his/her organization would feel a greater job satisfaction. In opposite, an employee without organizational commitment would find the job less satisfactory.

Lee and Mowday (1987) mentions that job satisfaction and organizational commitment are related. The organizational commitment has a reciprocal impact on job satisfaction. It means that if an employee finds a job satisfactory, then he/she will have a strong commitment towards the organization. Reciprocally, an employee with a strong commitment towards his/her organization will feel a greater satisfaction from his/her job (Sudiro, 2008); Westover et al., (2010).

Researches done by Gunz dan Gunz (1994), Knoop (1995) serta Young et al.(1998) discovers the existence of correlation between job satisfaction and organizational commitment. This result is similar to some other studies: a research conducted by Martin \& O'Loughlin (1984), which shows that job satisfaction in a battalion of US Army consistently impacts the enhancement of organizational commitment; a research by Carmeli et al. (1984), which finds out that job satisfaction has impact on job commitment and achievements; another one by Westover, et al. (2010) which observes 215 employees of a social organization in US as its sample and concludes that oganizational commitment has a significant impact on job satisfaction. On the other hand, Yiing and Zaman (2009) presents an opposite result, that is: organizational commitment have a significant negative impact towards job satisfaction. Based on the controversy of the research results above, the writer develops the third, fourth, and fifth hypothesis as follows:

H3: Organizational commitment has positive impact on lecturers' job satisfaction.

H4: Job performance as a mediator variable in determining the impact of organizational commitment on the lecturers' job satisfaction.

H5: Reward system as a moderator variable in determining the impact of organizational commitment on the lecturers' job satisfaction.

\section{METHODS OF RESEARCH}

This is a causality research. The sample is a part from the whole population of lecturers working at A-graded private colleges in East Java (the grades are given by the National Accreditation Board for Higher Education/BAN-PT), which is comprised of 10 private colleges in Surabaya and Malang. This research uses stratified random sampling method with 105 people as the sample. The data are acquired from the distribution of questionnaires. From 200 questionnaires that were distributed, 95 were returned in a complete manner. Validity and reliability test have proved all the items in this research variables as valid and reliable. The validand-reliable data were then tested using Generalized Structured Component Analysis (GeSCA). 


\section{RESULTS OF STUDY}

GeSCA Structural Model Test Result. This research uses GeSCA model; reward system becomes a moderator variable between lecturer's job performance and job satisfaction, and there is also a mediator variable between the correlation of commitment to job satisfaction. The correlation between indicators and latent variables is completely reflexive. Here are table 4.1 and figure 4.1 containing GeSCA calculations with mediation and moderation.

\section{Table 1. GeSCA Structural Model Result}

\begin{tabular}{|c|c|c|c|c|c|}
\hline \multirow{2}{*}{ Variable Correlation } & \multicolumn{3}{|c|}{ Direct impact } & \multirow{2}{*}{$\frac{\text { Indirect impact }}{\text { Estimate }}$} & \multirow{2}{*}{$\begin{array}{l}\text { Information on mediation } \\
\text { and moderation attribute }\end{array}$} \\
\hline & Estimate & SE & CR & & \\
\hline COMMITMENT (X1) -> PERFORMANCE (Y1) & 0.191 & 0.066 & 2.06 & - & - \\
\hline PERFORMANCE (Y1) -> SATISFACTION (Y2) & 0.433 & 0.075 & 5.74 & - & - \\
\hline COMMITMENT (X1) -> SATISFACTION (Y2) & 0.217 & 0.065 & $3.31^{*}$ & 0.299 & Full Mediation \\
\hline REWARD SYSTEM (Z) -> SATISFACTION (Y2) & 0.024 & 0.094 & 0.26 & - & - \\
\hline INTERACTION Z*Y1-> SATISFACTION (Y2) & 0.274 & 0.065 & 4.24 & - & Pure Moderation \\
\hline
\end{tabular}

$C R^{*}=$ significant at $\alpha=0.05$ level.

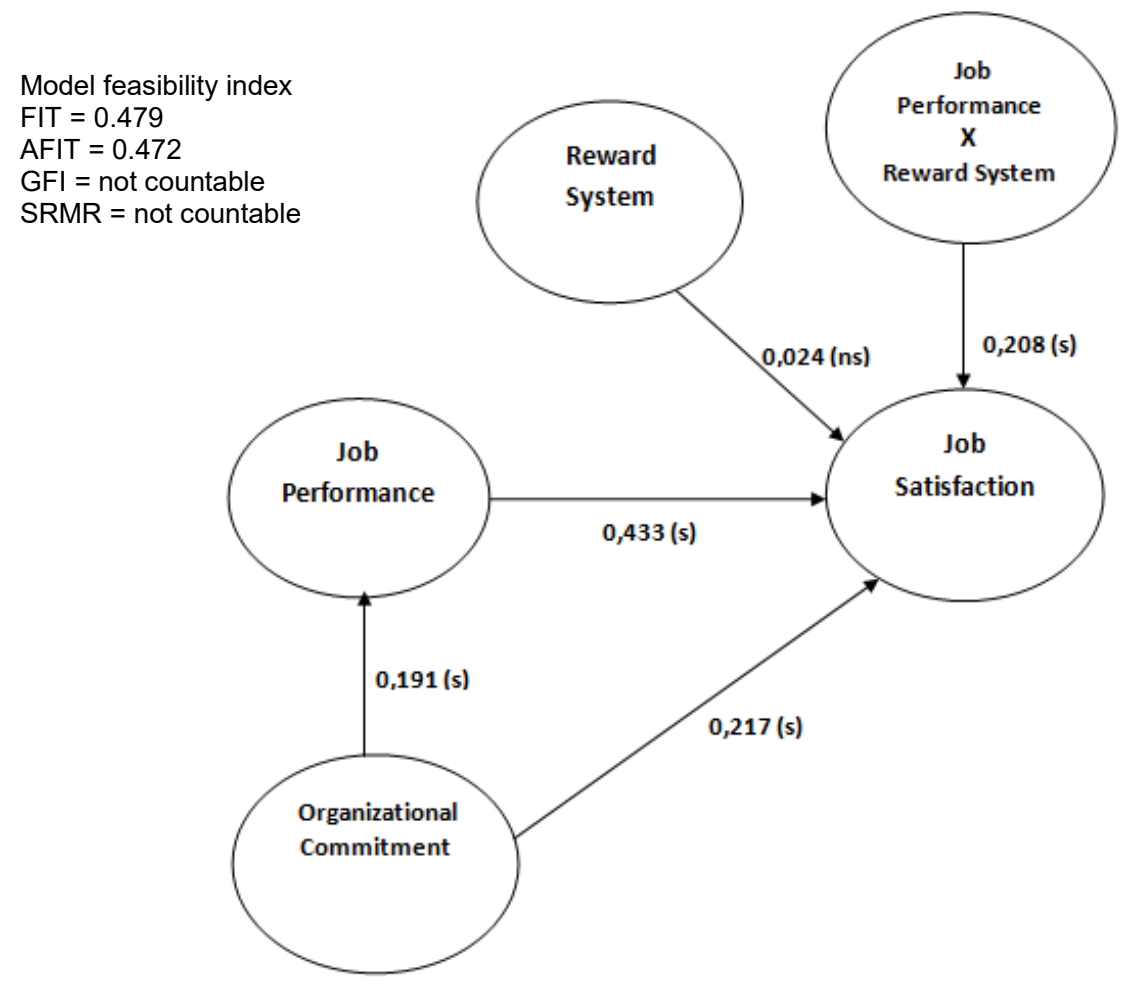

Figure 1 - GeSCA Modelling with Moderation

According to Table 1 above, the path coefficient $0.191 \quad(C R=2.06)$ representing correlation between organizational commitment and lecturers' job performance is significant. path coefficient $0.217(\mathrm{CR}=3.31)$ representing the correlation between organizational commitment and lecturers' job satisfaction is significant. The path coefficient 0.433 $(C R=5.74)$ representing the correlation between job performance and lecturers' job satisfaction is significant. The path coefficient $0.024(\mathrm{CR}=0.26)$ representing the correlation between reward system and lecturers' job satisfaction is not significant. Meanwhile, the path coefficient $0.208(\mathrm{CR}=4.10)$ representing the correlation between the interaction of job performance \& reward system and lecturers' job satisfaction is significant. The last two coefficient test results prove that reward system is attributed as pure moderation. 
Hypotheses Testing. There are five hypotheses in this research: three hypotheses concerning direct impact, one concerning mediated impact, and the last one concerning moderated impact. Here are the results on the three hypotheses.

H1: Organizational commitment has a positive impact towards lecturers' job performance.

The path coefficient $0.191(\mathrm{CR}=2.06)$ representing correlation between organizational commitment and lecturers' job performance is significant with positive direction. The lecturers' job performance will improve if they have stronger organizational commitment, which means hypohtesis $\mathrm{H} 1$ in this research is acceptable.

H2: Job performance has a positive impact on lecturers' job satisfaction.

The path coefficient $0.433(\mathrm{CR}=5.74)$ representing the correlation between job performance and lecturers' job satisfaction is significant with positive direction. Lecturers with good job performance will find a greater satisfaction from his/her job, which means hypothesis $\mathrm{H} 2$ in this research is acceptable.

H3: Organizational commitment has positive impact on lecturers' job satisfaction.

The path coefficient $0.217 \quad(\mathrm{CR}=3.31)$ representing the correlation between organizational commitment and lecturers' job satisfaction is significant with positive direction. Lecturers who have stronger organizational commitment will gain more satisfaction from his/her job, which means hypothesis $\mathrm{H} 3$ in this research is acceptable.

H4: Job performance as a mediator variable in determining the impact of organizational commitment on the lecturers' job satisfaction.

The path coefficient 0,299 representing the indirect correlation of organizational commitment towards lecturers' job satisfaction through lecturers' job performance is significant with positive direction. The test result explains that job performance acts as a full mediation between the lecturers' organizational commitment and job satisfaction. Lecturers who have stronger organizational commitment which are mediated by a good job performance will gain greater job satisfaction, which makes hypothesis $\mathrm{H} 4$ in this research acceptable.

H5: Reward system as a moderator variable in determining the impact of organizational commitment on the lecturers' job satisfaction.

The path coefficient $0.433(\mathrm{CR}=5.74)$ representing the correlation between job performance and lecturers' job satisfaction is significant with positive direction. The path coefficient $0.024(C R=0.26)$ representing the correlation between reward system and lecturers' job satisfaction is not significant. The path coefficient $0.208(C R=4.10)$ representing the correlation between the the interaction of job performance \& reward system and lecturers' job satisfaction is significant with positive direction. The test result explains that reward system acts as a pure moderation between the lecturers' job performance and satisfaction.

The job satisfaction will be greater in lecturers who has good job performance and whose workplace/college gives a suitable reward system; this means hypothesis H5 in this research is acceptable.

\section{DISCUSSION OF RESULTS}

Based on the hypotheses testing above, the writer could map the correlations between variables as follows.

The Impact Of Organizational Commitment Towards Job Performance $(X 1 \rightarrow Y 1)$. From the test result of the first hypothesis, path coefficient $0.191(C R=2.06)$ representing correlation between organizational commitment and lecturers' job performance is significant with positive direction. This means that the first hypothesis, stating that organizational commitment has a positive impact towards lecturers' job performance, is verified/acceptable. The path coefficient has a postitive mark, which theoretically means that impact of organizational commitment towards job performance is a one way correlation. This indicates that lecturers who have stronger organizational commitment will also have better job performance. Whereas the lecturers who have a weaker organizational commitment may experience a decline in their job performance. 
Normative commitment $\left(\mathrm{X}_{.1 .2}\right)$ with loading factor of 0.835 and continuance commitment $\left(\mathrm{X}_{.1 .3}\right)$ with loading factor of 0.803 become important indicators in reflecting the organizational commitment towards the job performance of lecturers working in tri dharma supporting department (education, research \& development, community service) (Y.1.4) variable, with loading factor of 0,811 dan towards the job performance of lecturers working in teaching department $\left(\mathrm{Y}_{.1 .1}\right)$ with loading factor of 0,778 . It could be interpreted that a lecturer's commitment is reflected in his/her strength of will to stay working in the organization and in the strong feeling that he/she would suffer a loss should he/she quit from the organization.

This research result corresponds with Darwito (2008), Burton (2002), Jaramillo, et al. (2005), and Sudiro (2008), whose research results show that organizational commitment has a positive impact towards the employees' job performance. However, it differs with Wiener and Vardi (1980); Mathieu and Zajac's (1990); and Yiing and Zaman (2009), whose research results state that organizational commitment does not give a direct impact on job performance.

The Impact of Job Performance Towards Job Satisfaction $\left(\mathrm{Y}_{1} \rightarrow \mathrm{Y}_{2}\right)$. From the test result of the second hypothesis, path coefficient jalur $0.433 \quad(C R=5.74)$ representing correlation between job performance and lecturers' job satisfaction is significant with positive direction. This means that the second hypothesis, stating that job performance has a positive impact towards lecturers' job satisfaction is verified/acceptable. The path coefficient has a postitive mark, which theoretically means that impact of job performance towards lecturers' job satisfaction is a one way correlation. This indicates that lecturers who have better job performance will also experience greater job satisfaction. Whereas the lecturers who have a poorer job performance may experience a lack of job satisfaction.

The indicator of work performance of lecturers who work in tri dharma supporting department $\left(\mathrm{Y}_{.1 .4}\right)$ has a loading factor of 0.811 meanwhile that of lecturers in teaching department $\left(\mathrm{Y}_{.1 .1}\right)$ has a loading factor of 0.778 . These become dominant indicators in reflecting the following variables: job performance toward lecturers' job satisfaction about supervision $\left(\mathrm{Y}_{.2 .3}\right)$ with loading factor of 0.856; and lecturers' job satisfaction towards coworkers $\left(\mathrm{Y}_{.2 .5}\right)$ with loading factor of 0.838 . It could be interpreted that a lecturer's job performance is reflected in his/her efforts, be it doing better in tri dharma or teaching the students in a better way.

This research result corresponds with Lawler and porter (1967); Siegel and Bowen (1971); Stumpf and Hartman (1984); Karatepe and Tekinkus (2006), which state that employees' job performance will impact their job satisfaction.

The Impact of Organizational Commitment Towards Job Satisfaction $(X 1 \rightarrow Y 2)$. From the test result of the third hypothesis, the path coefficient $0.217(C R=3.31)$ representing correlation between organizational commitment and lecturers' job satisfaction is significant with positive direction. This means that the third hypothesis, stating that organizational commitment has a positive impact towards lecturers' job satisfaction, is verified/acceptable. The path coefficient has a postitive mark, which theoretically means that impact of organizational commitment towards job satisfaction is a one way correlation. This indicates that lecturers who have stronger organizational commitment will also experience greater job satisfaction. Whereas the lecturers who have a weaker organizational commitment may experience a lack of satisfaction from their job.

Normative commitment $\left(X_{1.2}\right)$ with loading factor of 0.835 and continuance commitment $\left(X_{1.3}\right)$ with loading factor of 0.803 become important indicators in reflecting the following variables: job performance toward lecturers' job satisfaction about supervision $\left(Y_{.2 .3}\right)$ with loading factor of 0.856; and lecturers' job satisfaction towards co-workers ( $\left.\mathrm{Y}_{.2 .5}\right)$ with loading factor of 0.838 . It could be interpreted that a lecturer's commitment is reflected in his/her strength of will to stay working in the organization and in the strong feeling that he/she would suffer a loss should he/she quit from the organization.

This research result corresponds with Sudiro (2008); Westover et al. (2010); who state that employees with strong organizational commitment will experience a greater satisfaction from their jobs. However, it is contrary with Yiing and Zaman (2009) whose result conveys that organizational commitment has significant negative impact on job performance. 
The Impact of Organizational Commitment Towards Job Satisfaction Through Job Performance) $(X 1 \rightarrow Y 1 \rightarrow Y 2)$. The test shows that: the organizational commitment's direct impact on job performance is significant with a positive direction, job performance's direct impact on job satisfaction is also significant with positive direction, and the organizational commitment's direct impact on job satisfaction, too, is significant with a positive direction. Therefore, path coefficient $\left\{0.217+\left(0.191^{*} 0.433\right)\right\}=0.299$ representing organizational commitment's indirect impact on job satisfaction through job performance is significant and positive. This means that the fourth hypothesis, stating that job performance as a mediator variable in determining the impact of organizational commitment on the lecturers' job satisfaction, is verified/acceptable.

The path coefficient has a postitive mark, which theoretically means that impact of organizational commitment towards job satisfaction is a one way correlation.

This indicates that lecturers who have stronger organizational commitment will also experience greater job satisfaction. Whereas the lecturers who have a weaker organizational commitment may experience a lack of satisfaction from their job.

This research result corresponds with the study by Bono et al. (2001), which state that job performance is used as a mediator variable to investigate impact of organizational commitment towards job satisfaction.

The Impact of Reward System As A Moderator Variable In Determining The Impact of Organizational Commitment On The Lecturers' Job Satisfaction (Y1* $Z \rightarrow Y 2)$. From the result of the testing of fifth hypothesis, the path coefficient $0.433(C R=5.74)$ representing the impact of lecturers' job performance towards job satisfaction is significant with a positive direction. The path coefficient $0.024(\mathrm{CR}=0.26)$ representing the correlation between reward system and lecturers' job satisfaction is not significant. The path coefficient $0.208(C R=4.10)$ representing the correlation between the interaction of job performance \& reward system and lecturers' job satisfaction is significant with positive direction. The test result explains that reward system acts as a pure moderation to the correlation between lecturers' job performance and job satisfaction.

The path coefficient has a postitive mark, which theoretically means that the impact of the interaction job satisfaction is a one way correlation. The job satisfaction will be greater in lecturers who has good job performance and whose workplace/college provides a suitable reward system. Contrariwise, the sense of job satisfaction will decrease in lecturers who have good job performance, but the workplace/college cannot provide a suitable reward system.

The involvement in tasks $\left(Z_{.1 .3}\right)$ has a loading factor of 0.773 ; and significance of tasks $\left(Z_{1.2}\right)$ has a loading factor of 0.747 . These become the dominant indicators to reflect rewars system variable, which has a loading factor of 0.773 . This could be interpreted as follows: how much a reward system is desired by an lecturer/employee is reflected from the his/her involvement in tasks given by the organization/employer.

This research result corresponds with the study by Porter and Lawler (1971) which concludes that reward system moderates the correlation between of job performance towards job satisfaction, and also the study by Ivancevich (1979) which concludes that intrinsic reward system moderates the correlation between of job performance towards job satisfaction. It means that a lecturer's good job performance will not automatically result in a greater job satisfaction. The job satisfaction will increase for the lecturers with both good job performance and provision of suitable reward system from the organization/college.

Implications of the Research. This research result provides a practical implication that private colleges should give more attention to the lecturers' job performance and job satisfaction, because lecturers' betterment of job performance will help the college to progress, develop, and keep the organization's continuity in the increasingly tough competition. Therefore, it is important for the head of private colleges to pay attention to factors that enhance lecturers' job performance and satisfaction, such as motivation-building, lecturers' competency upgrading through continuous trainings in developing learning methods, experiment skills, national and international scientific journal skills; and also enhance the organizational commitment through implementation of policies and rules, and 
creating good academic atmosphere. In addition, the suitable reward system-whether material or nonmaterial-would be very helpful to enhance the lecturers' job satisfaction. For the lecturers, nonmaterial rewards (being involved/assigned in organizational tasks) are more preferred as their means of self-actualization than material rewards.

Limitations of the Research. The research results still have limitations in these regards:

1. The research scope has not yet covered all the private-owned colleges in East Java: it is limited only to those which are accredited with an A grade.

2. During the distribution of questionnaires to the respondents, the writer had trouble in personally meeting and doing in-depth-interview with the respondents. Therefore, in some study programs, the writer distributed the questionnaires through the head of program, and does the interview with the head of the study program. This may cause respondents to have a perception bias on the questionnaires distributed.

3. This research is only temporarily valid: only during the period around when the questionnaires were distributed; so if there are changes in the lecturers' job performance and satisfaction, it cannot be accessed continuously. Hence, the results cannot be generalized as a long-term correlation between organizational commitment and job satisfaction variables.

\section{CONCLUSION}

Based on the purpose and result of the research, conclusions can be made as follows:

1. Organizational commitment has a positive impact on lecturers' job performance. The stronger organizational commitment is, the higher job performance of the lecturers can improve.

2. Job performance has a positive impact on lecturers' job satisfaction. The better job performance they have, the more job satisfaction they obtain.

3. Organizational commitment has a positive impact on lecturers' job satisfaction. The stronger organizational commitment is, the more job satisfaction the lecturers obtain.

4. Job performance mediates the correlation between organizational commitment and job satisfaction. Organizational commitment will improve job performance and furthermore the lecturers' job satisfaction.

5. Reward system moderates the correlation between lecturers' job performance and job satisfaction. The job satisfaction will be greater in lecturers who has good job performance if the college gives a suitable reward system.

\section{REFERENCES}

1. Allen, N. J., and Meyer, J.P. 1990, The measurement and antecedents of affective, continuance, and normative commitment to organization. Journal of occupational psychology, 63, 1-18.

2. Bono, J.E, Judge, T.A., Thoresen, C.J. and Patton, G.K., 2001, The job satisfaction-job performance relationship: a qualitative and quantitative review. Psycological Bulletin, Vol. 127 No. 3, pp. 376-407

3. Burton, E., Gene, 2002, Jepang vs Amerika Serikat: Sebuah Perbandingan Lingkungan Perusahaan dan Karakteristik, Manusia Manajemen Sistem, 8 (2), 167-173.

4. Brayfield, A.H. and Crockett, W.H. 1955. Employee attitudes and employee performance. Psycological Bulletin, 52, 396-424.

5. Carmeli, A. and Freund, A. 2004." Work commitment, job satisfaction and job performance: An empirical investigation", International Journal of Organisation Theory and Behaviour, vol 7 No. 3, pp. 289-309

6. Chen, Z.X. and Francesco, C., 2003, The relationship between the three components of commitment and employee performance in china. Journal of Vacational Behaviour, Vol. 62 No. 3, pp. $490-510$ 
7. Darwito, 2008, Analisis Pengaruh Gaya Kepemimpinan Terhadap Kepuasan Kerja Dan Komitmen Organisasi Untuk Meningkatkan Kinerja karyawan (Studi Pada RSUD Kota Semarang). http://eprints.undip.ac.id/16933/1/DARWITO.pdf

8. DeCotiis, T. and Summers, T., 1987, A path analysis of a model of the antecedents and consequences of organizational commitment. Human Relations, Vol. 40, pp. 445-70.

9. Gagnon, M.A. and Michael, J.H., 2004, Outcomes of perceived supervisor support for wood production employees. Forest Product Journal, Vol. 54 No. 12, pp. 172-7

10. Giddens, A., 2001, Runaway Word, London: Profile Books Ltd

11. Gunz, H.P. and Gunz S.P., 1994, Profesional/organizational commitment and job satisfaction for employed lawyers. Human Relations, 47, pp. 801-817

12. Herzberg, F., Mausner, B., Peterson R.O. and Capwell, D.F., 1957, Job Attitude: Review of Research and Opinion, Pittsburgh PA, Psychological service of Pittsburgh.

13. Ivancevich, John M., 1999. Organizational behavior and Management. Fifth edition.New York: Mc Graw-Hill.

14. Jaramillo F., J.P. Mulki, and G.W. Marshall, 2005, A Meta-analysis of the relationship between organizational commitment and salesperson job performance: 25 years of research. Journal of Business Research 58, pp.705-714

15. Joyce, W. and Slocum, J.W., 1984, Collective climate: agreement as a basis for defining aggregate climates in organizations. Academy of Management Journal, Vol. 27 No. 4, pp. 721-42

16. Joyce, W. and Slocum, J.W. and Glinow, M.A., 1982, Person-situation interaction: competing models of fit. Journal of Occupational Behaviour, Vol. 3 No. 4, pp. 265-80.

17. Judge, T.A., Thoresen, C.J., Bono, J.E and Patton, G.K., 2001, The job satisfaction-job performance relationship: a qualitative and quantitative review. Psycological Bulletin, Vol. 127 No. 3, pp. 376-407

18. Karatepe M.O. and Tekinkus M., 2006, The effects of work family conflict, emotional exhaustion, and intrinsic motivation on job outcomes of front line employees. International Journal of Bank Marketing, Vol. 24 no. 3, pp. 173-193.

19. Knoop, R., 1995, Relationship among job involvement, job satisfaction and organizational commitment for nurses. The Journal of Psychology, 129, pp. 643-649.

20. Laffaldano, M.T. \& Muchinsky, P.M., 1985, Job Satisfaction and Job Performance: A Meta-analysis, Psychological Bulletin, pp. 251-273

21. Lawler, E.E. and Porter, L.W., 1967, The effect of performance on job satisfaction, Industrial Relations, October 1967, pp. 20-8

22. Lee, T.W. \& Mowday, R.T. 1987. Voluntarily leaving an organization: An empirical investigation of Steers and Mowday's of turnover. Academy Management Journal. 721743

23. Locke, E.A., 1970, Job Satisfaction and Job Performance: A Theoritical Analysis, Organizational Behaviour and Human Performance, pp. 484-500

24. Martin, T.N. and M.S. O'Laughlin, 1984, Predictors of organizational commitment: The study of part-time army reservists. Journal of vocational Behaviour, Vol. 25 No. 3, pp. 270-283

25. Mathieu, J.E., \& Zajac, D.M. 1990. A review and meta-analysis of the antecedents, correlates, and cobsequences of organizational commitment. Psychology Bulletin, 108: 171-194

26. Meyer, J.P. and N.J. Allen, 1997, Commitment in the workplace: Theory, Research, and Application. Thousand Oaks, CA: Sage Publication, Inc

27. Michael, J.H., Evans, D.D., Jansen, K.J. and Haight, J.M., 2005, Management commitment to safety as organizational support: relationships with non-safety outcomes in wood manufacturing employees. Journal of Safety Research, Vol. 36 No. 2, pp. 171-9.

28. Miller, R.I., 1980, Appraising institutional performance, Improving Academic Management, USA: John Wiley and Sons

29. Orpen, C., 1986, The effect of job performance on the relationship between job satisfaction and turnover. Journal of social psychology, Vol. 126 No. 2, pp. 277-8 
30. Petty, M.M., McGee, G.W., \& Cavender J.W. 1984. A Meta-analysis of the relationships between individual job satisfaction and individual performance. Academy of Management review, 712-721

31. Porter, L.W. and Lawler, E.E., 1968, Managerial Attitudes and Performance, Dorsey Press, Homewood, IL

32. Roethlisberger, F.J. and Dickson, W.J. 1939. Management and the Worker, Harvard University Press, Cambridge, MA

33. Sallis, E., 2002, Total Quality Management in Education, London: kogan Page Limited.

34. Schwab, D.P. and Cummings, L.L. 1970. Theories of Performance and Satisfaction: A Review. Industrial Relations, 9, 408-430.

35. Siegel, J.P. and Bowen, D., 1971, Satisfaction and performance: causal relationships and moderating effects. Journal of Vocational Behavior, Vol. 1, pp. 263-9

36. Stumpf, S.A. and Hartman, K., 1984, Individual exploration to organizational commitment or withdral. Academy of Management Journal, Vol. 27, pp. 308-29

37. Sudiro Achmad, 2008, Pengaruh Timbal Balik Anatara Kepuasan Kerja dengan Kepuasan Keluarga dan Komitmen Kerja serta Dampaknya terhadap Prestasi Kerja dan Karier Dosen, Jurnal Manajemen dan Kewirausahaan, Vol. 10 No.1, hal. 38-49, Universitas Kristen Petra Surabaya.

38. Vroom, V.H., 1964, Work and Motivation. Wiley, New York, NY.

39. Westover H. Jonathan, A.R. Westover, and A.L. Westover, 2010, Enhancing long-term worker productivity and performance: The connection of key work domains to job satisfaction and organizational commitment. International Journal of Productivity and Performance Management, Volume 59 Iss: 4, pp 372-387

40. Wiener, Y. \& Vardi, Y. 1980. Relationships between job organization and career commitment and work outcomes-an integrative approach. Organizational Behavior and Human Performance, pp 81-96.

41. Yiing H.Lee. and K. Zaman Bin Ahmad, 2009, The moderating effects of organizational culture on the relationships between leadership behavior and organizational commitment and between organizational commitment and job satisfaction and performance. Leadership \& Organization Development Journal, vol. 30 No. 1, pp. 53-86.

42. Young, B.S., S. Worchel, and D.J. Woechr, 1998, Organizational commitment among public service employee. Public Personal Management, pp. 339-348

43. Zimmerman D. Ryan and T.C. Darnold, 2009, The impact of job performance on employee turnover intentions and the voluntary turnover process. A meta analysis and path model. Personal review, Vol 38 no 2, pp. 142-158. 